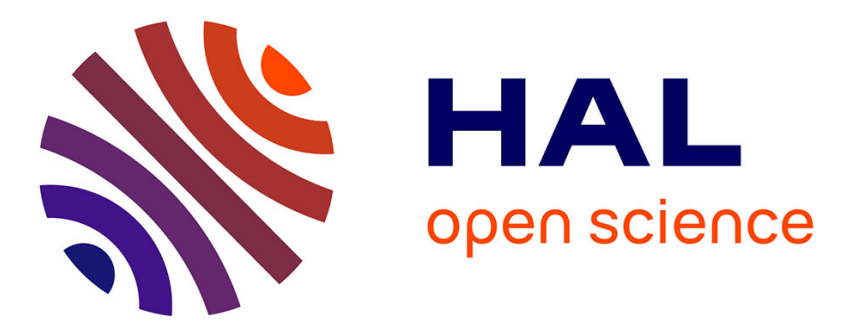

\title{
Microdissection: a tool for bee chromosome studies
} Anderson Fernandes, Patrícia Scudeler, Débora Diniz, Fausto Foresti, Lucio Campos, Denilce Lopes

\section{To cite this version:}

Anderson Fernandes, Patrícia Scudeler, Débora Diniz, Fausto Foresti, Lucio Campos, et al.. Microdissection: a tool for bee chromosome studies. Apidologie, 2011, 42 (6), pp.743-748. 10.1007/s13592011-0082-0 . hal-01003620

\section{HAL Id: hal-01003620 https://hal.science/hal-01003620}

Submitted on 1 Jan 2011

HAL is a multi-disciplinary open access archive for the deposit and dissemination of scientific research documents, whether they are published or not. The documents may come from teaching and research institutions in France or abroad, or from public or private research centers.
L'archive ouverte pluridisciplinaire HAL, est destinée au dépôt et à la diffusion de documents scientifiques de niveau recherche, publiés ou non, émanant des établissements d'enseignement et de recherche français ou étrangers, des laboratoires publics ou privés. 


\title{
Microdissection: a tool for bee chromosome studies
}

\author{
Anderson Fernandes ${ }^{1,2}$, Patrícia Elda Sobrinho Scudeler ${ }^{3}$, \\ Débora DINIZ ${ }^{4}$, Fausto Foresti ${ }^{3}$, Lucio Antônio de Oliveira CAMPOS ${ }^{1}$, \\ Denilce Meneses LOPES ${ }^{1}$ \\ ${ }^{1}$ Departamento de Biologia Geral, Universidade Federal de Viçosa, Av. P H Rolfs, s/n, CEP: 36.570-000, Viçosa, \\ Minas Gerais, Brazil \\ ${ }^{2}$ Departamento de Ciências Biológicas, Universidade do Estado de Mato Grosso, Tangará da Serra, Mato Grosso, \\ Brazil \\ ${ }^{3}$ Departamento de Morfologia, UNESP, Botucatu-SP, Distrito de Rubião Júnior, s/n, CEP: 18.618-000, Botucatu, \\ São Paulo, Brazil \\ ${ }^{4}$ Departamento de Ciências Biológicas (DCB), Universidade Estadual do Sudoeste da Bahia-UESB, José Moreira \\ Sobrinho, s/n, CEP: 45206-190, Jequié, Bahia, Brazil
}

Received 6 October 2010 - Revised 29 March 2011 - Accepted 4 April 2011

\begin{abstract}
The emergence of new molecular biology techniques has provided cytogenetics with tools which allow for the elucidation of questions that classical cytogenetics could not answer. Therefore, the present work standardizes a microdissection protocol for cytogenetic studies in bees. This methodology was first used in these insects and may contribute greatly to studies involving chromosomal rearrangements, heterochromatin composition, B chromosomes and others. For this study, the centromeric region of chromosomes in the stingless bee Tetragonisca fiebrigi was used for probe synthesis. The results demonstrated that the methodology used was efficient, presenting markings in the centromeric regions of several chromosomes. Hybridization in other sites indicates that the probe was able to detect regions that present homology with its sequence. This indicates that the technique is effective to study chromosomal evolution, genome organization and even the origin of B chromosomes.
\end{abstract}

Tetragonisca / Hymenoptera / cytogenetics / FISH / microdissection

\section{INTRODUCTION}

The tribe Meliponini includes what are commonly referred to as indigenous stingless bees. There are hundreds of species distributed in tropical regions of the world and in subtropical regions of the Southern Hemisphere (Silveira et al. 2002). Most species of this group are economically and ecologically important due to their role in the pollination of cultivated and wild

Corresponding author: D.M. Lopes, denilce.lopes@ufv.br

Manuscript editor: Marina Meixner plants and for the production of honey by some species (Michener 2000).

Cytogenetic studies on bees of the tribe Meliponini began with Kerr (1948). Since then, much data have been obtained, but almost all the information generated is based on classical cytogenetic techniques ( $\mathrm{C}$ band, Ag-NOR band and fluorochromes).

The advance of molecular biology techniques associated with cytogenetics in a field known as molecular cytogenetics has allowed for many improvements. Techniques such as microdissection and fluorescent in situ hybridization (FISH) has especially contributed to cytogenetic studies, 
making them new alternatives for research on the genome structure of organisms. This methodology eventually established a connection between classical cytogenetics and molecular genetics allowing for a series of applications, such as the production of specific probes, chromosome painting and physical genome mapping (Zhou and $\mathrm{Hu}$ 2007), including the visualization of rearrangements and polymorphisms not detected by conventional cytogenetics (Guerra 2004). This modality of study offers a greater resolution in chromosome analyses and enables the location of target sites in any portion of the karyotype.

The use of microdissection for cytogenetic studies was first described in the 1990s by Kao (1990) and later by Meltzer et al. (1992). Since then, it has been applied in the study of several groups of organisms, but no report for bees.

Therefore, the present work proposes the standardization of a methodology for the use of microdissection followed by the construction of specific probes for the study of chromosomes. To achieve this, the centromeric region of Tetragonisca fiebrigi was chosen for probe synthesis. This advance will significantly contribute to the cytogenetics study of bees by providing a tool that can aid in the understanding of chromosome evolution dynamics in bees and other Hymenoptera.

\section{MATERIALS AND METHODS}

In this work, a colony of T. fiebrigi was used as collected in the municipality of Tangará da Serra, in

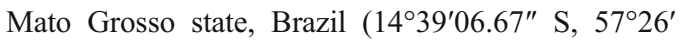
$02.31 " \mathrm{~W})$. The mitotic metaphase chromosomes were obtained according to the methodology of Imai et al. (1988) from the cerebral ganglia of larvae in the defecation stage. The material was prepared on a $24 \times$ 60-mm coverslip to facilitate microdissection.

\subsection{Microdissection and probe labelling}

The microdissection was carried out with the use of a micromanipulator (Eppendorf ${ }^{\circledR}$ ) attached to an inverted microscope (Zeiss ${ }^{\circledR}$, AXIOvert 100 model). The coverslips were stained with Giemsa, and six centromeric regions of the largest chromosome of pair 1 were microdissected (Figure 1a-c).

After microdissection, the centromeric regions were placed in a microtube containing the reaction mix (Table I) for amplification by degenerate oligonucleotide-primed PCR (DOP-PCR; Telenius et al. 1992). By using degenerate primers, this technique allows the nonspecific amplification of any DNA segment. Three DOP-PCR procedures were carried out under the conditions presented below:

- First DOP-PCR-Amplification of the microdissected material was carried out according to the protocol described by Mühlmann-Diaz et al. (2001), with some modifications. The microtubes with the mix (without polymerase) were warmed to $95^{\circ} \mathrm{C}$ for $10 \mathrm{~min}$ ( $\mathrm{min}$ ). This solution was briefly centrifuged, after which Termosequenase (Thermo Sequenase Cycle Sequencing Kit, USB) was added. The PCR reactions were carried out in a MJ Mini ${ }^{\mathrm{TM}}$, Bio-Rad Thermocycler. The programme consisted of $3 \mathrm{~min}$ at $94^{\circ} \mathrm{C}$, followed by 12 cycles of $1 \mathrm{~min}$ and $30 \mathrm{~s}$ at $94^{\circ} \mathrm{C}$, $2 \mathrm{~min}$ at $37^{\circ} \mathrm{C}, 1 \mathrm{~s}$ at $37^{\circ} \mathrm{C}$ with an increase of $0.2^{\circ} \mathrm{C}$ per second until reaching $72^{\circ} \mathrm{C}$, remaining for $2 \mathrm{~min}$ at this temperature. The 12 cycles were followed by a second stage of 30 cycles of $1 \mathrm{~min}$ and $30 \mathrm{~s}$ at $94^{\circ} \mathrm{C}, 1 \mathrm{~min}$ at $62^{\circ} \mathrm{C}$, and $1 \mathrm{~min}$ and $30 \mathrm{~s}$ at $72^{\circ} \mathrm{C}$.

- Second DOP-PCR-Using $2 \mu \mathrm{L}$ of the product from the first DOP-PCR, a conventional PCR was performed to obtain a stock. The amplification programme was composed of an initial step of $3 \mathrm{~min}$ at $94^{\circ} \mathrm{C}$, followed by 30 cycles of $1 \mathrm{~min}$ and $30 \mathrm{~s}$ at $90^{\circ} \mathrm{C}, 1 \mathrm{~min}$ and $30 \mathrm{~s}$ at $56^{\circ} \mathrm{C}$, and $1 \mathrm{~min}$ and $30 \mathrm{~s}$ at $72^{\circ} \mathrm{C}$, followed by $10 \mathrm{~min}$ at $72^{\circ} \mathrm{C}$.

- Third DOP-PCR-This DOP-PCR was carried out for marking of the probe with fluorescence. The amplification conditions were the same as those used for the second DOP-PCR, with the exception of including marked nucleotides using dUTP-digoxigenin.

At each amplification, a sample of the products were applied in $1 \%$ agarose gel and $1 \times$ TBE with molecular weight markers to assess the size of the amplified fragments, which should be between 300 and $600 \mathrm{bp}$ (Figure 1d). 

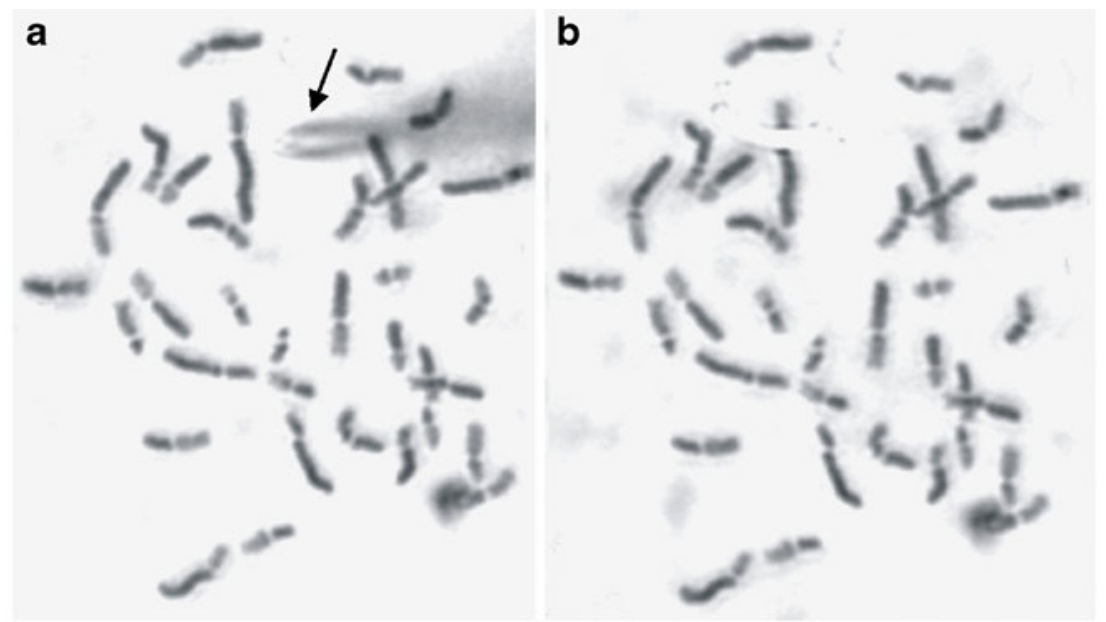

C
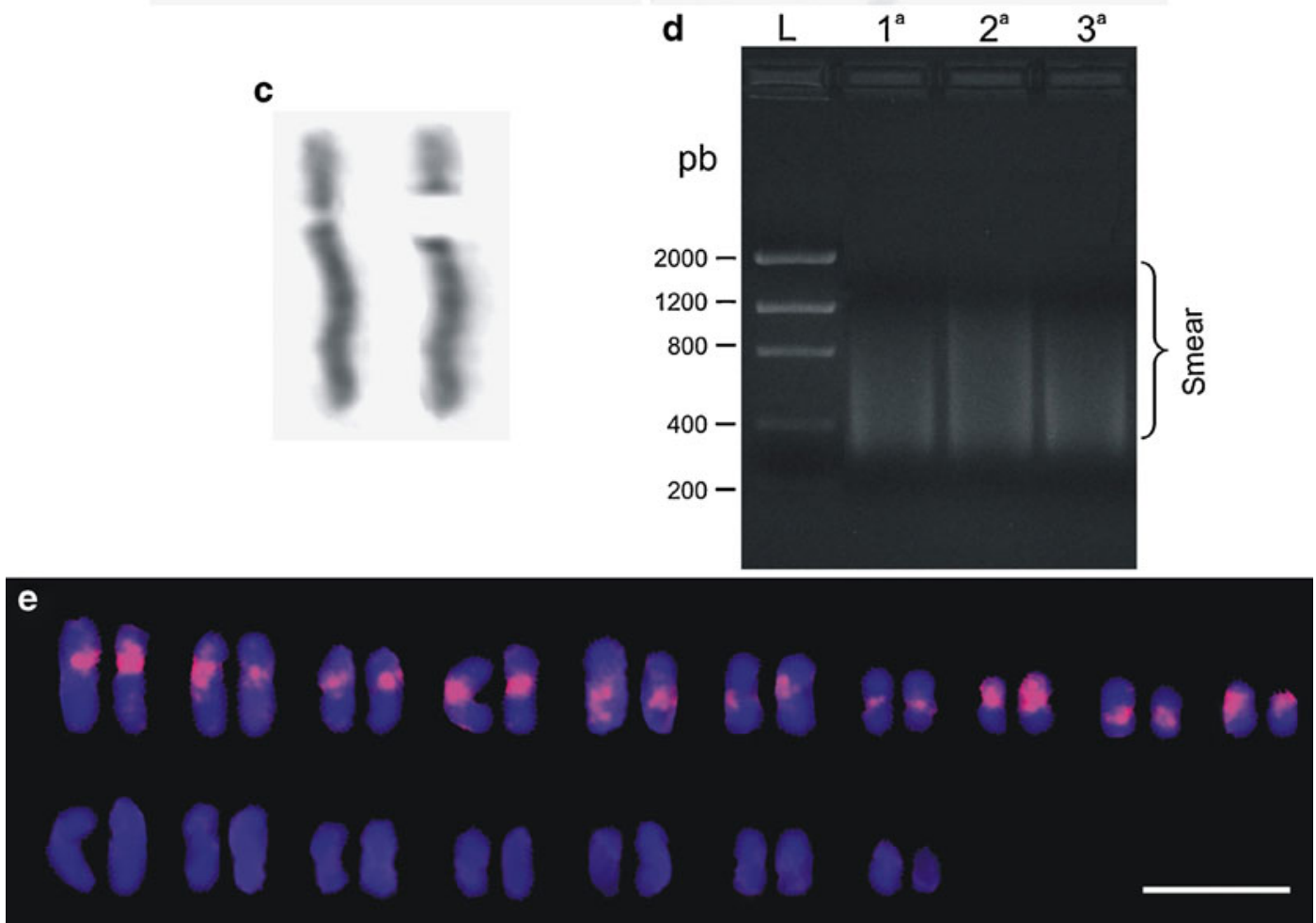

Figure 1. a Metaphase of T. fiebrigi before microdissection. The arrow shows the microneedle. b Metaphase after microdissection. $\mathbf{c}$ The microdissected centromeric region in detail. d Electrophoresis of the products of the three DOP-PCR procedures. $L$ ladder molecular. e Karyotype marked with the centromeric probe: first line, chromosomes with centromeric marking; second line, unmarked chromosomes. Bar $=5 \mu \mathrm{m}$.

\subsection{In situ hybridization}

The FISH methodology employed was based on that of Pinkel et al. (1986), with modifications. The slides with the chromosomal preparation were washed in $1 \times$ PBS buffer for 5 min under agitation and then dehydrated in an alcohol series of $70 \%, 85 \%$ and $100 \%$ (cold) for $5 \mathrm{~min}$ each. Next, they were 
Table I. Amplification conditions of DOP-PCR.

\begin{tabular}{llll}
\hline Mix & 1st DOP & 2nd DOP & 3rd DOP \\
\hline DNTPs & $0.2 \mathrm{mM}$ & $0.04 \mathrm{mM}$ & $\begin{array}{l}\text { dATP, dCTP, dGTP-0.04 mM } \\
\text { dTTP-0.028 mM }\end{array}$ \\
& & & $\begin{array}{l}\text { dUTP-digoxigenina-0.012 mM } \\
\text { Buffer }\end{array}$ \\
Primer $^{\mathrm{a}}$ & $1 \times$ & $1 \times$ & $1 \times$ \\
$\mathrm{MgCl}_{2}(\mathrm{mM})$ & $2 \mathrm{mM}$ & $0.8 \mu \mathrm{M}$ & $0.8 \mu \mathrm{M}$ \\
Polymerase $^{\mathrm{b}}(\mathrm{U} / \mu \mathrm{L})$ & 2.0 & 2.0 & 2.0 \\
DNA & 4 & 0.05 & 0.05 \\
Final volume $(\mu \mathrm{L})$ & 6 centromeres & $2 \mu \mathrm{L}$ & $2 \mu \mathrm{L}$ \\
\hline
\end{tabular}

The values presented refer to the final concentrations of the solutions of each DOP-PCR. All reactions received the addition of $\mathrm{H}_{2} \mathrm{O}$ to their final volume

${ }^{a}$ Degenerated primers were used (5' CCGACTCGAGNNNNNNATGTGG 3') in all the reactions, in accordance with Telenius et al. (1992)

${ }^{\mathrm{b}}$ For the first DOP, the polymerization enzyme Termosequenase was used, whilst Taq polymerase Phoneutria was used for the second and third DOP-PCRs; the buffers recommended by the manufacturers were used together with both enzymes

incubated in $100 \mu \mathrm{L}$ of RNAse $(0.4 \%$ RNAse, $2 \times$ $\mathrm{SSC})$ at $37^{\circ} \mathrm{C}$ for $1 \mathrm{~h}$ in a humid chamber and then washed three times for $5 \mathrm{~min}$ in $2 \times \mathrm{SSC}$ and for $5 \mathrm{~min}$ in $1 \times$ PBS. The slides were incubated again for $10 \mathrm{~min}$ at $37^{\circ} \mathrm{C}$ in pepsin $0.005 \%(10 \mathrm{mM} \mathrm{HCl})$ and washed in $1 \times$ PBS during 5 min under agitation. They were then fixed in $1 \%$ formaldehyde, $1 \times$ PBS, $50 \mathrm{mM} \mathrm{MgCl}$ for $10 \mathrm{~min}$, followed by washing in $1 \times$ PBS for 5 min under agitation.

This was followed by dehydration in alcohol series of $70 \%, 85 \%$ and $100 \%$ (cold), for 5 min each. Simultaneously, the hybridization solution was denatured at $100^{\circ} \mathrm{C}$ for $10 \mathrm{~min}$ and placed on ice. About $1.5 \mu \mathrm{g}$ of the probe marked with the fluorochrome of interest was used.

After dehydration, the chromosomal DNA was denatured with $70 \%$ formamide in $2 \times \mathrm{SSC}$ at $70^{\circ} \mathrm{C}$ for $5 \mathrm{~min}$ and dehydration in the alcohol series was again performed. The slides were then mounted with $50 \mu \mathrm{L}$ of hybridization solution and placed in a humid chamber overnight at $37^{\circ} \mathrm{C}$. They were then washed two times in $15 \%$ formamide, $0.2 \times \mathrm{SSC}$, $\mathrm{pH} 7.0$, at $42^{\circ} \mathrm{C}$ for $10 \mathrm{~min}$, three times in $0.1 \times \mathrm{SSC}$ at $60^{\circ} \mathrm{C}$ for $5 \mathrm{~min}$ each and, finally, in $0.5 \%$ Tween, $4 \times$ SSC for $5 \mathrm{~min}$. The slides were incubated in $5 \%$ nonfat dried milk (NFDM), $4 \times$ SSC buffer for $15 \mathrm{~min}$ and washed twice with $0.5 \%$ Tween, $4 \times$ SSC.
After these washings, the slides were incubated with $100 \mu \mathrm{L}$ of anti-digoxigenin rhodamine conjugated $(5 \mu \mathrm{L}$ anti-digoxi rhodamine and $995 \mu \mathrm{L}$ NFDM) for $1 \mathrm{~h}$ in a humid chamber, in the dark, at room temperature and washed three times for $5 \mathrm{~min}$ with $0.5 \%$ Tween, $4 \times \mathrm{SSC}$ at room temperature. Dehydration in alcohol 70\%, 85\% and 100\% (5 min each) was then carried out again. The slides were mounted with $40 \mu \mathrm{L}$ of a DAPI+antifading solution (VECTASHIELD Mounting Medium with DAPI, Vector Laboratories) and placed in the dark. To verify the efficiency of the FISH, a previously tested $18 \mathrm{~S}$ DNA probe was used as a positive control.

Metaphases were analyzed under an epifluorescence microscope, Olympus BX60.

\section{RESULTS AND DISCUSSION}

In Figure 1a-c, the centromeric region can be observed, which was microdissected and later amplified by DOP-PCR. The result of the three DOP-PCR procedures, via microdissection of the centromeric blocks of chromosome 1 of six metaphases revealed that most fragments presented a size of about 300-600 bp (Figure 1d), which was appropriate for the FISH procedure 
as suggested by Telenius et al. (1992). The DOP-PCR technique was effective and satisfactory in terms of the production of chromosomespecific probes.

Figure 1e presents a metaphase with the markings achieved by the probe of the centromeric region in several chromosomes. However, marking was not observed in all the chromosomes. This may indicate that the centromeric region does not present the same sequence for all chromosomes of this species. Satellite DNA in the centromere is usually much longer than is necessary for centromeric function (Plohl et al. 2008); therefore, the amplified region may represent a sequence that does not constitute a basic building block of the centromeric chromatin. Even within a genome, distinct forms of satellite DNA can accumulate mutations with different rates, adding to the diversity of sequence patterns in pericentromeric areas (Plohl et al. 2008).

The hypothesis of chromosome evolution in this group suggests events of heterochromatin fission and amplification in one arm for the stabilization of telomeres (Imai et al. 1986). Ten chromosomes presented markers, which may have originated from the same chromosome group, whilst the others arise from one conjunct with distinct centromeric or pericentromeric regions.

Markings in other locations besides the centromeric region were observed. The microdissected region comprised not only the centromere (Figure 1c) but also a small part of the chromosome arms. The species $T$. fiebrigi has a heterochromatic arm in all chromosomes, and part of these regions was also amplified, which may be the cause of these markings. This suggests that the region close to the centromere has sequences similar to those in other regions of the heterochromatin and that this heterochromatin is similar since several chromosomes were marked.

The hybridization of the probe in other regions besides the centromeres indicates that the probe was able to detect regions that present homology with its sequence. This demonstrates that the technique is effective to study chromosomal evolution, origin of extra chromosomes and even genome organization. The same results were observed in other studies using regions of heterochromatin (unpublished data).

In insects, several studies have been realized by the use of microdissection. Bugrov et al. (2007) used this methodology to elucidate the origin of $\mathrm{B}$ chromosome, suggesting an independent origin of B chromosomes in two closely related grasshopper Podisma species. Likewise, Bressa et al. (2009) examined the structure, molecular differentiation and meiotic behaviour of Dysdercus albofasciatus neo-sex chromosomes by microdissection and FISH. However, to our knowledge, there are no reports about the use of this methodology for bees and other Hymenoptera.

Therefore, the most important goal of this work was to present the possibility of constructing probes based on the microdissection of partial chromosomes and, eventually, even whole chromosomes, which may contribute to cytogenetic and evolutionary studies of bees.

\section{ACKNOWLEDGEMENTS}

We thank the Fundações de Amparo à Pesquisa de São Paulo (Fapesp), Minas Gerais (Fapemig) and Mato Grosso (Fapemat), the Coordenação de Aperfeiçoamento de Pessoal de Nível Superior (CAPES), and the Conselho Nacional de Desenvolvimento Científico e Tecnológico (CNPq) for their financial support.

\section{Microdissection: un outil pour étudier les chromo- somes des abeilles.}

Tetragonisca / Hymenoptera / cytogénétique / FISH

\section{Mikrodissektion: eine Methode für Chromosomen- studien an Bienen.}

Tetragonisca / Hymenoptera / cytogenetik / FISH / mikrodissektion

\section{REFERENCES}

Bressa, M.J., Papeschi, A.G., Vítková, M., Kubíčková, S., Fuková, I., Pigozzi, M.I., Marec, F. (2009) Sex chromosome evolution in cotton stainers of the genus Dysdercus (Heteroptera: Pyrrhocoridae). Citogenet. Gen. Res. 125, 292-305 
Bugrov, A.G., Karamysheva, T.V., Perepelov, E.A., Elisaphenko, E.A., Rubtsov, D.N., WarchałowskaS'liwa, E., Tatsuta, H., Rubtsov, N.B. (2007) DNA content of the B chromosomes in grasshopper Podisma kanoi Storozh. (Orthoptera, Acrididae). Chromos. Res. 15, 315-325

Guerra, M. (2004) FISH: Conceitos e Aplicações na Citogenética. Sociedade Brasileira de Genética, Ribeirão Preto

Imai, H.T., Maruyama, T., Gojobori, T., Inoue, Y., Crozier, R.H. (1986) Theoretical bases for karyotype evolution. The minimum-interaction hypothesis. Am. Nat. 128, 900-920

Imai, H.T., Taylor, R.W., Crosland, M.W.J., Crozier, R.H. (1988) Modes of spontaneous evolution in ants with reference to the minimum interaction hypothesis. Jpn. J. Genet. 63, 159-185

Kao, T.T. (1990) Microdissection and microcloning of human chromosome 21. Proc. Clinic. Biol. Res. 360, 89-104

Kerr, W.E. (1948) Estudos sobre o gênero Melipona. Anais da E. S. A. "Luiz de Queiroz" 5, 182-276

Meltzer, P.S., Guan, X.Y., Burggess, A., Trent, J.M. (1992) Rapid generation of region specific probes by chromosome microdissection and their application. Nat. Genet. 1, 24-28
Michener, C.D. (2000) The bees of the world. The Johns Hopkins University Press, Baltimore

Mühlmann-Diaz, M.C., Ulsh, B.A., Whicker, F.W., Hinton, T.G., Congdon, J.D., Robinson, J.F. (2001) Conservation of chromosome 1 in turtles over 66 million years. Cytogenet. Cell. Genet. 92(1-2), 139-143

Pinkel, D., Straume, T., Gray, J.W. (1986) Cytogenetic analysis using quantitative, high-sensitivity, fluorescence hybridization. Proc. Natl. Acad. Sci. 83, 2934-2938

Plohl, M., Luchetti, A., Meštrović, N., Mantovani, B. (2008) Satellite DNAs between selfishness and functionality: structure, genomics and evolution of tandem repeats in centromeric (hetero)chromatin. Gene 409, 72-82

Silveira, F.A., Melo, G.A.R., Almeida, E.A.B. (2002) Abelhas Brasileiras: sistemática e identificação. Belo Horizonte.

Telenius, H., Carter, N.P., Bebb, C.E., Nordenskjold, M., Ponder, B.A., Tunnacliffe, J. (1992) Degenerate oligonucleotide-primed PCR: general amplification of target DNA by a single degenerated primer. Genomics 8, 718-725

Zhou, R.N., Hu, Z.M. (2007) The development of chromosome microdissection and microcloning technique and its applications in genomic research. Cur. Genom. 8, 67-72 